\begin{tabular}{|l|l|l|l|}
\hline \multicolumn{1}{|c|}{ 学 位 論 文 要 旨 } \\
\hline 学位の種類 & 博 士 & 名 & 執 行 寛 \\
\hline & 学 位 論 文 題 目
\end{tabular}

\title{
Inducible nitric oxide synthase expression in various laryngeal lesions in relation to carcinogenesis, angiogenesis, and patients' prognosis
}

(邦題 : 様々な喉頭病変における誘導型一酸化窒素合成酵素の発現と癌化、血管新生、 及び予後への関与)

\section{共著者名}

野中 聡、片田 彰博、坂東 伸幸、荻野 武、片山 昭公、高原 幹 林 達哉、原渕 保明

(Acta Oto-Laryngologica, 2007; 127: 970-979 掲載）

\section{I . 研究目的}

誘導型一酸化窒素合成酵素（induced Nitric Oxide Synthase：iNOS）の発現誘導に伴い過剩に生成され た NO は生体自らの DNA を障害し、突然変異を誘発するなど、癌発生に強く関与すると考えられている。近 年、大腸癌、胃癌などの固形癌において iNOS が癌細胞周囲の血管内皮細胞、癌細胞自体に過剩発現してい る報告例が散見され、悪性腫瘍の臨床像および予後などと iNOS 発現との関係が検討されている。しかし、 頭頸部悪性腫瘍を対象とした検討はほとんどおこなわれていない。一方、腫瘍の増殖、進展には血管新生が 必要不可欠であるが、この血管新生に関与する重要な因子として p53 癌抑制遺伝子や腫瘍細胞からも分泌さ れる血管内皮増殖因子（Vascular Endothelial Growth Factor：VEGF）があげられる。p53 癌抑制遺伝子は 血管新生を強力に抑制し、同時に VEGF の発現も抑制するといわれている。さらに、p53 癌抑制遺伝子の別 の機能として iNOS mRNA の転写抑制があるが、変異型 p53 はこの抑制作用を持たないため iNOS 誘導え進に 伴う 過剩な NO 産生が恒常的に持続することが知られている。また NO は VEGF 発現の上流のシグナルであ ると推測され、腫瘍組織の血管新生を促進させることで腫瘍の増殖、進展を誘発することが示唆される。 
したがって、腫瘍組織の血管新生には p53 癌抑制遺伝子、VEGF、およびN O の相互が密接に関与する可能性 が推測される。

本研究では様々な喉頭病変における iNOS の発現の有無を検討し、その癌化過程や血管新生においてどの ように関与しているか免疫組織学的手法を用いて解析した。さらに臨床因子、予後との関係についても検討 した。

\section{II . 材料・方法}

\section{1. 患者検体}

1990 年から 2001 年までに旭川医大耳鼻咽喉科・頭頸部外科にて治療を行ない、追跡可能であった喉頭扁 平上皮癌（喉頭 SCC 群）63 例（男性 58 例、女性 5 例、中央値 67 歳）を対象とした。原発部位別分類では 声門上が 30 例（48\%)、声門が $(41 \%)$ 、声門下が（11\%）であった。TN 分類では T1 が 20 例（32\%）、T2 が 29 例 $(46 \%) 、 \mathrm{~T} 3$ が 6 例 $(10 \%) 、 \mathrm{~T} 4$ が 8 例（12\%）であり、N(-)が 47 例（75\%)、N(+)が 16 例（25\%）であった。 治療方法は 63 例中 25 例（40\%）に放射線単独療法を施行した。38 例（60\%） は喉頭全摘術を行ない、N $(+)$ の症例については頸部郭清術を合わせて施行した。全症例の平均観察期間は 31 か月（2-135 か月）であっ た。さらに 5 例の正常喉頭上皮、 7 例の喉頭ポリープ、20 例の喉頭異形成 (9 例が mild/moderately dysplasia、 11 例が severe dysplasia）も本検討の対象とした。研究使用にあたっては患者より十分な説明をおこない 同意を得た。

\section{2. 免疫組織学的解析}

治療前の生検時もしくは初期治療時に採取された組織のホルマリン固定パラフィン包埋切片を材料にし て iNOS、p53、VEGF、及び血管新生の程度を表す微小血管密度（Micro Vesse1 Density：MVD）の指標とし てCD31 を免疫組織学的に検討した。まず脱パラフィン後、内因性ペルオキシダーゼのブロッキングを行な

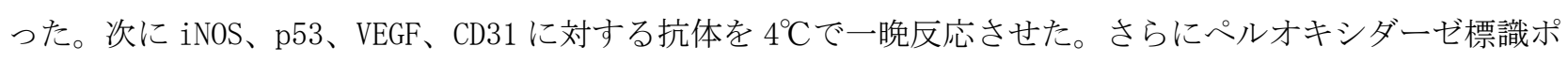
リマーで反応させ、DAB にて発色した。免疫組織の結果判定は以下の基準にしたがった。iNOS は染色強度 (200 倍で検鏡）をスコア 0 :染色なし、スコア 1 :弱陽性、スコア 2 : 中等度陽性、スコア 3 :強陽性の 4 段階にスコ ア化し、さらに領域（40 倍で検鏡）をスコア 0 :染色陽性なし、スコア 1 :染色陽性の腫瘍細胞が $25 \%$ 未満、 スコア $2: 25 \%$ 以上 $50 \%$ 未満、スコア $3: 50 \%$ 以上 $75 \%$ 未満、スコア $4: 75 \%$ 以上の 5 段階に分類した。染色強度と 領域の和をiNOS スコア $(0-7)$ として算出し、iNOS スコア 3 以上を iNOS 発現陽性とした。p53 は腫瘍細胞 の $10 \%$ 以上核が濃染し過剩発現していたものを陽性とした。VEGF は腫瘍細胞の 25\%以上の細胞質が濃染し 過剩発現していたものを陽性とした。MVD は 40 倍検鏡下で血管新生の最も盛んな部位を同定したのち、200 倍検鏡下で一視野中の微小血管数を算定した。これを各部位について 3 回行ない、その平均数を微小血管密 度とした。

3. 統計解析 
2 因子間の検定には Mann-Whitney のU 検定、カイ 2 乗検定またはFisher exact test を用いた。iNOS ス コアと微小血管密度（MVD）との相関はSpearman の順位相関検定を用いた。無病生存率については Kaplan-Meier 法による解析とCox 比例ハザードモデルによる単変量解析と多変量解析をおこなった。いず れも $\mathrm{p}<0.05$ を有意とした。

\section{III. 成績}

1. iNOS、p53 およびVEGF の発現

正常喉頭上皮（5 例）、声帯ポリープ（7 例）では iNOS、p53 および VEGF の発現をいずれも認めなかった。 しかし、mild/moderately dysplasia（9 例）では、iNOSの発現は 2 例 $(22 \%) 、 p 53$ の発現は 2 例 $(22 \%) 、$ VEGF の発現は 2 例（22\%）に認めた。 severe dysplasia（11 例）では、iNOS の発現は 4 例（36\%)、p53の 発現は 3 例 $(27 \%) 、 V E G F$ の発現は 4 例 $(36 \%)$ に認めた。喉頭扁平上皮癌では 63 例中、iNOS の発現は 36 例 $(57 \%) 、 p 53$ の発現は 28 例（44\%)、VEGF の発現は 30 例（48\%）に認めた。iNOS、p53 および VEGF の発現 陽性率はいずれも喉頭病変が mild/ moderately, severe dysplasia, 扁平上皮癌と重症化するに伴って増 加していた（p=0.0012、p=0.042、p=0.029）。

2. 喉頭粘膜異形成と喉頭扁平上皮癌における iNOS、p53、VEGF、MVD の発現の関与

喉頭粘膜異形成において p53 陽性例は p53 陰性例に比較して iNOS スコアが有意に高かった（iNOS score= 3. 00：3.00-4.50 vs 0.00：0.00-2.00，p=0.0007)。また、VEGF 発現もp53 陽性例では p53 陰性例に比較 して有意に高かった（ $\mathrm{p}=0.0004 ） 。 一$ 方、喉頭 S C C 症例では VEGF 陽性例はVEGF 陰性例に比較して iNOS スコアや MVD が有意に高かった（iNOS score=4.00：0.00-6.00 vs 0.00：0.00-3.00，p<0.0001；MVD=48.0： 34. 0-60.0 vs 24.0: 19.8-30.3，pく 0.0001)。さらに、iNOS スコアと MVD との間に有意な正の相関を認め た（r=0.869, p<0.0001)。しかし、p53の発現と VEGF、iNOS スコアおよびMVD との間に相関は認められ なかった。

3. 予後

年齢、性別、TN 分類、stage 分類はいずれも局所再発および遠隔転移に何ら関連を認めなかった。組織学 的分化度、初回治療、p53 発現も局所再発および遠隔転移に関連を認めなかった。しかし、初回治療後の局 所再発および遠隔転移を生じた症例は、局所再発および遠隔転移を生じなかった症例に対しiNOS スコアや MVD や VEGF 発現が有意に高かった（iNOS score=4.00：3.00-6.00 vs 2.00：0.00-4.00，p=0.001; MVD= 49. 0： 35. 0-56. 8 vs 27.5：22.0-45. 0, p=0.003; VEGF= 82.4\% vs 34.8\%， p=0.001)。Kaplan-Meier 法による解 析を行なったところ、iNOS 発現陽性群（ $\mathrm{p}=0.01 ） 、 \mathrm{VEGF}$ 発現陽性群（ $\mathrm{p}=0.003 ） 、$ 高 MVD（ $\geqq 50 ） （ \mathrm{p}=0.035 ）$ ではそれぞれ iNOS 発現陰性群、VEGF 発現陰性群、低 MVD $(<50)$ に比較して有意に 5 年無病生存率が低下し ていた。また、単変量解析の結果、これらの iNOS 発現陽性群(ハザード比 5.571，95\%信頼区間 1.273-24.383，

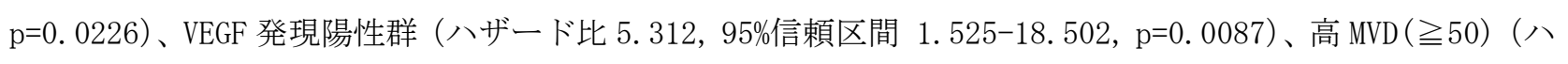


ザード比 2.706，95\%信頼区間 1.036-7.070， p=0.042）は有意に無病生存率の低下と関連していた。さらに 多変量解析で iNOS 発現陽性群（ハザード比 6.668，95\%信頼区間 1.126-39.476，p=0.0364） と VEGF 発現陽 性群（ハザード比 4.953，95\%信頼区間 1.124-21.827，p=0.0345）が無病生存率を規定する独立した予後因 子であることが判明した。

\section{IV. 考案}

本研究においては iNOS、p53、およびVEGF の発現が正常喉頭組織や喉頭ポリープでは認められず、 mild/moderately dysplasia から severe dysplasia、癌組織へと病変が重症化するにつれて発現が上昇し、 癌組織で最も発現が高いことが明らかとなった。このことは以前に報告された胃粘膜組織での検討（1）と 同様のものであり、iNOS、p53、および VEGF の発現増強が喉頭組織の癌化を促進させる早期の重要な役割を 果たすことを示唆するものであった。また、iNOS、p53、および VEGF の発現がどのように血管新生に関与し ているか検討したところ、喉頭癌組織において iNOS とVEGF の発現の間に有意な相関が認められた。NO は VEGF の上流のシグナルと言われ癌組織において血管新生を促進させることで癌の増殖を引き起こすとの報 告がある (2)。本研究の結果を考慮すると喉頭扁平上皮癌組織において iNOS の発現増強はVEGF の発現増加 を来たし、その結果として血管新生が誘発されることが示唆された。一方、喉頭扁平上皮癌組織において p53 の発現は INOS 発現や血管新生のいずれにも関連がなかった。本研究において予後因子について検討し たが、p53 過剩発現は予後と関連性を認めなかった。p53 遺伝子変異の検索には免疫組織学的に p53 過剩発 現を指標とするより遺伝子変異を直接シークエンス寸る方が正確であると言われており（3）今後の検討課 題であると考えられた。iNOS 発現の予後的価值は十分に検討されておらず、特に頭頸部領域においては報 告も少ない。本研究では iNOS 発現が喉頭扁平上皮癌における無病生存率に対する独立した予後因子である ことを示したものである。今回の成績は治療前の喉頭癌組織における iNOS の発現を解析することで、予後 の推測や症例によっては喉頭を温存できる否かを予見できる可能性を示唆するものであった。加えて治療前 における iNOS 発現の解析することで、癌再発の高リスク群を抽出したり、術後の補助療法を必要とする症 例を探る上での有益な情報を得る可能性が示唆された。

\section{V. 結論}

1. iNOS、p53、および VEGF の発現が正常喉頭組織や喉頭ポリープでは認められず、mild-moderately dysplasia, severe dysplasia, 癌組織 の順に発現は高くなっていた。

2. 喉頭粘膜異形成において p53 陽性例と iNOS スコア、VEGF 発現に有意な関連を認めた。

3. 喉頭扁平上皮癌では VEGF 陽性例と INOS スコアやMVD に有意な関連を認めた。さらに、iNOS スコアと MVD との間に有意な正の相関を認めた。

4. 初回治療後の局所再発および遠隔転移を生じた症例は、iNOS スコア、VEGF、MVD が有意に高值であっ 


$$
\text { た。 }
$$

5. 予後因子を解析したところ、iNOS 発現陽性群、VEGF 発現陽性群、高 MVD ( $\geqq 50)$ 群において有意に 5 年 無病生存率が低下していた。多変量解析で iNOS 発現陽性群と VEGF 発現陽性群が無病生存率を規定する 独立した予後因子であることが判明した。

6. 以上の結果より iNOS 発現が喉頭癌組織における血管新生、予後に重要な役割を果たしていると考えら れた。喉頭癌組織の INOS 発現を治療前に解析することは、癌再発の可能性を予測したり、術後に補助 療法を必要とするのかを判断するうえで有用であることが示唆された。

VI. 引用文献

1. Feng, C., Wang, L., Jiao, L., Liu, B., Zheng, S., Xie, X. Expression of p53, inducible nitric oxide synthase and vascular endothelial growth factor in gastric precancerous and cancerous lesions: correlation with clinical features. BMC Cancer, 2:8, 2002

2. Chiarugi, V., Magnelli, L., Gallo, O. Cox-2, iNOS and p53 as play-makers of tumor angiogenesis. Int J Mol Med, 2: 715-719, 1998

3. Kropveld, A., Slootweg, P. J., van Mansfeld, A. D., Blankenstein, M. A., Hordijk, G. J. Radioresistance and p53 status of T2 laryngeal carcinoma. Analysis by immunohistochemistry and denaturing gradient gel electrophoresis. Cancer, 78:991-997, 1996

V . 参考文献

1. 執行 寛、野中 聡、片山昭公、高原 幹、荻野 武、今田正信、林 達哉、原㴊保明. 七上喉頭癌に おける誘導型一酸化窒素合成酵素（iNOS）発現の検討．頭頸部腫瘍 29(1),230-234,2003

2. 執行 寬、斎藤 滋、高橋光明、原㴊保明. KTPレーザー治療を行なった口腔内多発性血管腫症例. 耳鼻 $\quad 46(5), 396-398,2000$ 
学位論文の審査結果の要旨

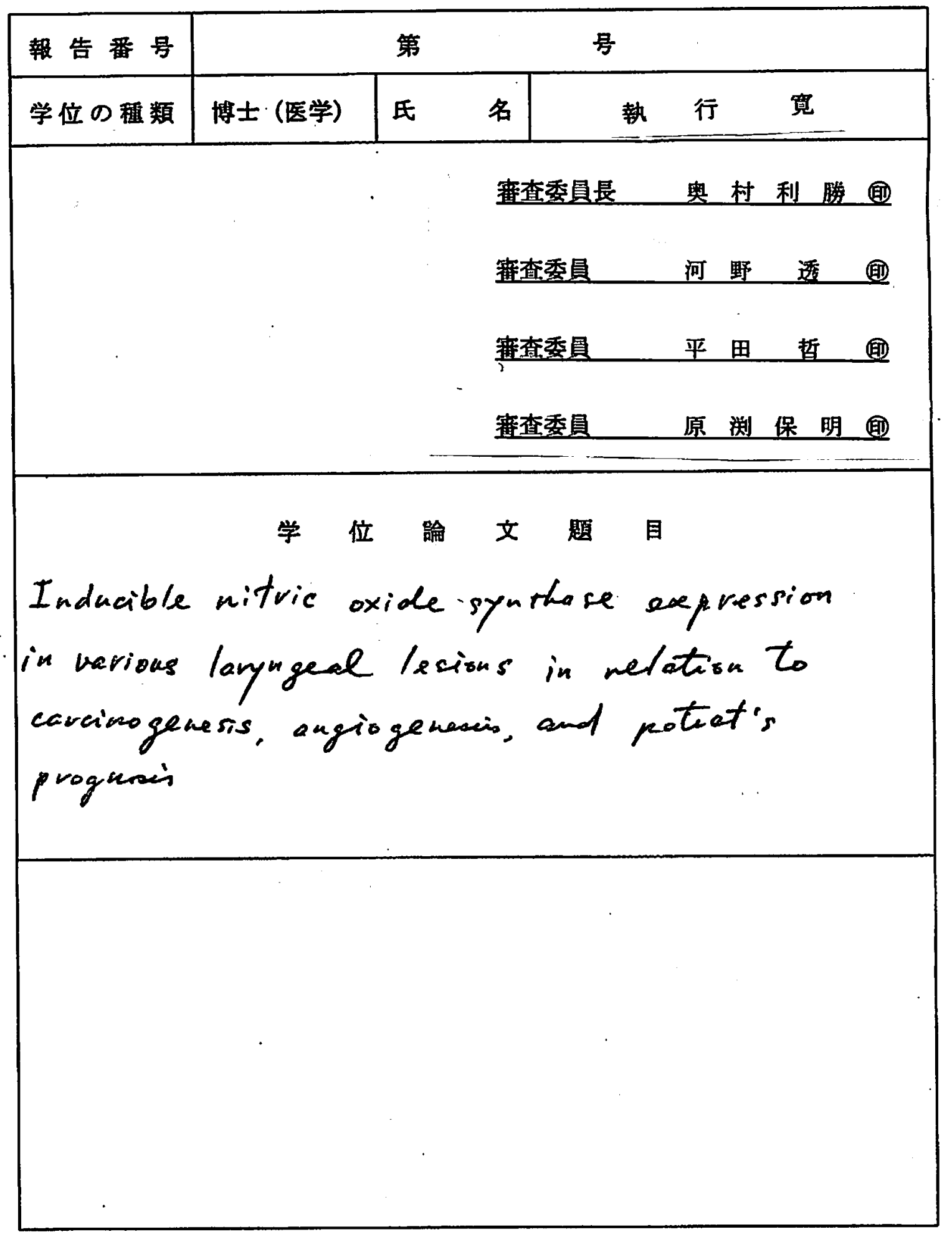




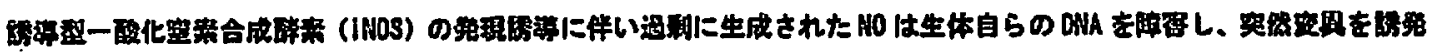

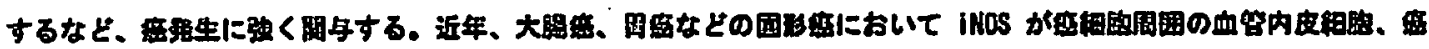

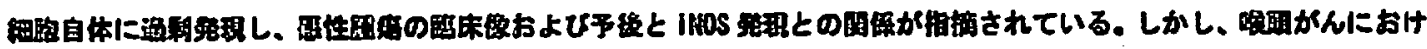

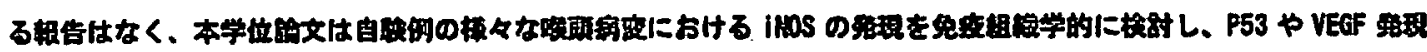

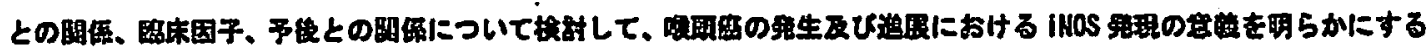
ために行われた。得られた勘果は以下の通りである。

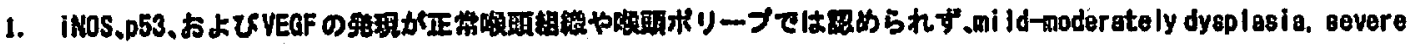

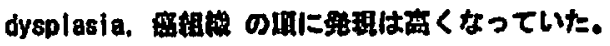

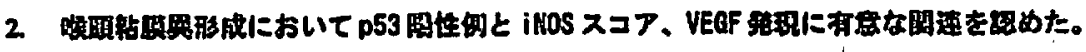

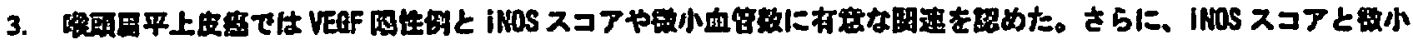

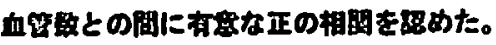

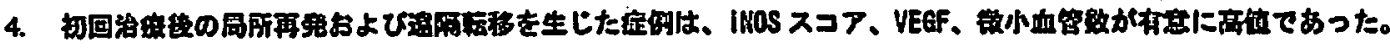

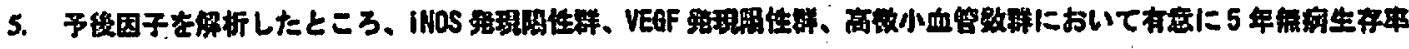

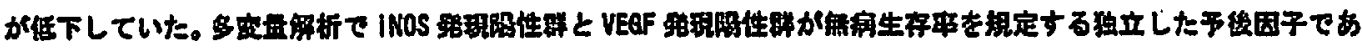
ることが蚂期した。

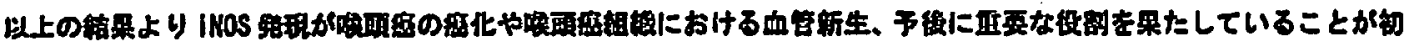
めて明らかにされた。これらの研究は

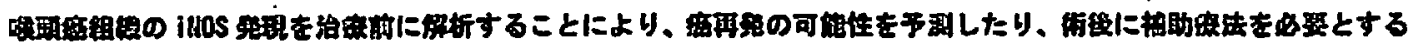

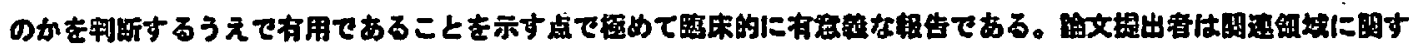

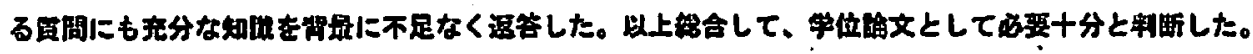

